POLITYKA ENERGETYCZNA - ENERGY POLICY JOURNAL

$2019 \downarrow$ Volume $22 \uparrow$ Issue $4 \uparrow 81-96$

DOI: $10.33223 / \mathrm{epj} / 110072$

\title{
Analysis of selected environmental regulations influencing the long-term operation of cogeneration companies
}

ABSTRACT: The article attempts to identify environmental conditions for the development of cogeneration companies in Poland. The article systematizes knowledge about environmental regulations which concern this issue. Within the framework of identified environmental conditions, the authors characterize issues related to national legislation that regulates the operation of cogeneration companies, as well as the requirements resulting from European Union and national regulations in this matter. These regulations, directly and indirectly, affect the long-term future of cogeneration companies and the energy sector as a whole. Undoubtedly, in the current state of environmental regulations in force, the key change for a power company such as a cogeneration company is to meet the requirements for the emission of harmful substances. The change was introduced in 2016 as a result of more stringent emission limits and the adoption of the IED (Industrial Emissions Directive). The implementation of recommendations of the BAT (Best Available Techniques) Conclusions in 2017

$\triangle$ Corresponding Author: Karol Stós; e-mail: karol.stos@wp.pl

1 Poland; ORCID iD: 0000-0002-4304-1107; e-mail: karol.stos@wp.pl

2 The Mineral and Energy Economy Research Institute of the Polish Academy of Sciences, Kraków, Poland; ORCID iD: 0000-0001-7514-8761; e-mail: kaminski@min-pan.krakow.pl

3 The Mineral and Energy Economy Research Institute of the Polish Academy of Sciences, Kraków, Poland; ORCID iD: 0000-0003-4587-9613; e-mail: malec@meeri.pl

2019. The Author(s). This is an open-access article distributed under the terms of the Creative Commons Attribution-ShareAlike International License (CC BY-SA 4.0, http://creativecommons.org/licenses/by-sa/4.0/), which permits use, distribution, and reproduction in any medium, provided that the Article is properly cited. 
additionally tightened the required limits. Undeniably, the key period for cogeneration companies will be 2021 as per the implementation of imposed harmful substances emission's limits. The article comprehensively discusses the conditions that substantially affect the long-term growth of a cogeneration company and are crucial when making assumptions intended to address strategic development issues in the domestic fuel and power sector.

KEYWORDS: environmental regulations, cogeneration, BAT conclusions

\section{Introduction}

Like other entities in the energy sector, companies producing in cogeneration units operate within a number of environmental regulations. The company's role is to act in accordance with applicable legal solutions, including environmental regulations. Accordingly, the current trend determined by the decarbonization policy pursued by the European economy is leading to tougher regulations, challenging the entire domestic fuel and power sector.

There are several basic ways in which a company can make a fundamental impact on the surrounding environment. From the point of view of the necessity to meet the environmental requirements, the emissions of substances to air, caused by the combustion of fuels during the production of electricity and heat are the most important. The main substances discharged into air include: $\mathrm{CO}_{2}, \mathrm{NO}_{\mathrm{x}}, \mathrm{SO}_{\mathrm{x}}$ and dust. Simultaneously, the combustion process produces solid waste (mainly ash and slag) which needs to be treated later. Waste water generated by the company has an equally significant impact on the environment; it is necessary as well to take the rational use of water in the company's operations into account. Other types of emissions with a harmful impact on the environment include, among others, noise emissions (Kucowski et al. 1997; Stala-Szlugaj 2012; Kamiński and Stós 2014).

Compliance with the emission requirements concerning the determined substances and factors constitutes the basis for the operation of a cogeneration company. Accordingly, further in this chapter, current and future environmental protection requirements resulting from EU and national regulations and applicable to a cogeneration company will be analyzed. In light of the above, this article aims to identify the conditions - from the key group of environmental conditions - which influence the operation of a cogeneration company in the long term. 


\section{Legislation regulating the operation of cogeneration companies}

As mentioned in the introduction, a company producing electricity, or heat and electricity, is obliged to meet certain requirements imposed by the legislator. The key documents currently governing the operation of cogeneration companies in terms of their environmental impact and environmental protection, are:

$\diamond$ integrated permit,

$\downarrow$ water-law permit,

$\checkmark$ other sectoral decisions/authorizations.

The first of the aforementioned documents is the so-called Integrated Permit on which the operation of a company is based. In the case of power plants, or CHP plants, an integrated permit is required if the installation is designed to burn fuels and has a nominal power greater than $50 \mathrm{MW}$.

The document is a specific administrative decision setting out the rules for introducing polluting substances or energy into the environment. Obtaining a permit makes it possible for industrial installations and other (e.g. municipal sewage treatment plants) to carry out their industrial activities. The scope of the integrated permit covers all environmental impacts specified in partial permits as well as their interrelationship. In the case of CHP plants, the integrated permit covers water intake, discharge of spent cooling water, emissions into air, and production waste, i.e. ash and slag (Zmysłowska and Nowakowski 2004).

Another document is the Water-Law Permit, which is an administrative decision specifying the conditions for using surface water and groundwater, and conducting inspections in this respect. Pursuant to Article 122 of the Water Law Act of 18 July 2001, water-law permits are required primarily for specific water use and execution of water apparatus, as well as for other activities contained in that provision and which may affect the status of water (Wastewater Treatment Manual 2010).

\section{Analysis of environmental regulations influencing the operation of cogeneration companies}

From the point of view of a company carrying out the fundamental task, i.e. production of heat and electricity in a CHP plant, depends not only on market conditions (supply and demand), but also on environmental regulations adopted at the European Union level, which directly and indirectly shape the long-term future of both the power sector and the mining sector. Therefore, 
further in this chapter, current and future environmental protection requirements resulting from $\mathrm{EU}$ and national regulations and applicable to a cogeneration company will be analyzed.

\subsection{Tougher emission reduction regulations resulting from the Industrial Emissions Directive}

Due to very strong pressure at the European Union level to reduce the impact of industry, transport, and other sectors of the economy which affect significantly the environment, the current regulations and requirements are gradually being tightened. A significant change for the power sector was the tightening of the requirements resulting from the provisions of the Industrial Emissions Directive (IED) adopted by the European Parliament and the Council on 24 November 2010. The directive imposed very stringent limits on emissions of sulphur dioxide, nitrogen oxides and dust in order to prevent and control pollution on large industrial units, both existing and new (fuel combustion units with a power greater than $50 \mathrm{MW}$ ).

The emission standards for cogeneration companies were not very strict before 2016 . The companies were able to meet the emission standards because they used fuel with low sulphur content and an appropriate calorific value, as well as dust extraction systems using electrostatic precipitators.

The IED brought together all the directives dedicated to the power sector into a single package. A single document grouped regulations concerning all types of business activity, regulations resulting from the system of integrated permits, regulations concerning volatile organic compounds, waste incineration, large combustion plants, etc. separately. Emission standards were also significantly tightened (Figs. 1-3). It should also be noted that for $\mathrm{NO}_{\mathrm{x}}$, the specified emission level became effective in 2018 , as a result of a longer transition period.

Changes initiated by the implementation of the Industrial Emissions Directive were introduced into the Polish legislation as part of the amendments to the Act of 27 April 2001 - Environmental Protection Law. This also entailed changes to the integrated permits held. Moreover, the IED obliged entities to conduct continuous measurements of $\mathrm{SO}_{\mathrm{x}}, \mathrm{NO}_{\mathrm{x}}$ and dust concentrations for combustion plants (within a new meaning of the term) with a rated thermal input greater than $100 \mathrm{MW}$, and also imposed a requirement to conduct measurements of total mercury emissions from coal-fired plants, at least once every year. However, given the importance of the power sector in the economies of the Member States, some derogation mechanisms were negotiated allowing participants in the sector, cogeneration companies included, to spread the required changes (and the resulting costs) over time.

The IED provided for four such solutions:

1) Transitional National Plan - Member States were allowed to introduce a gradual emission reduction mechanism in 2016-2020 so that after 30 June 2020 all the installations will meet at least the requirements set out in Annex V of the IED. 


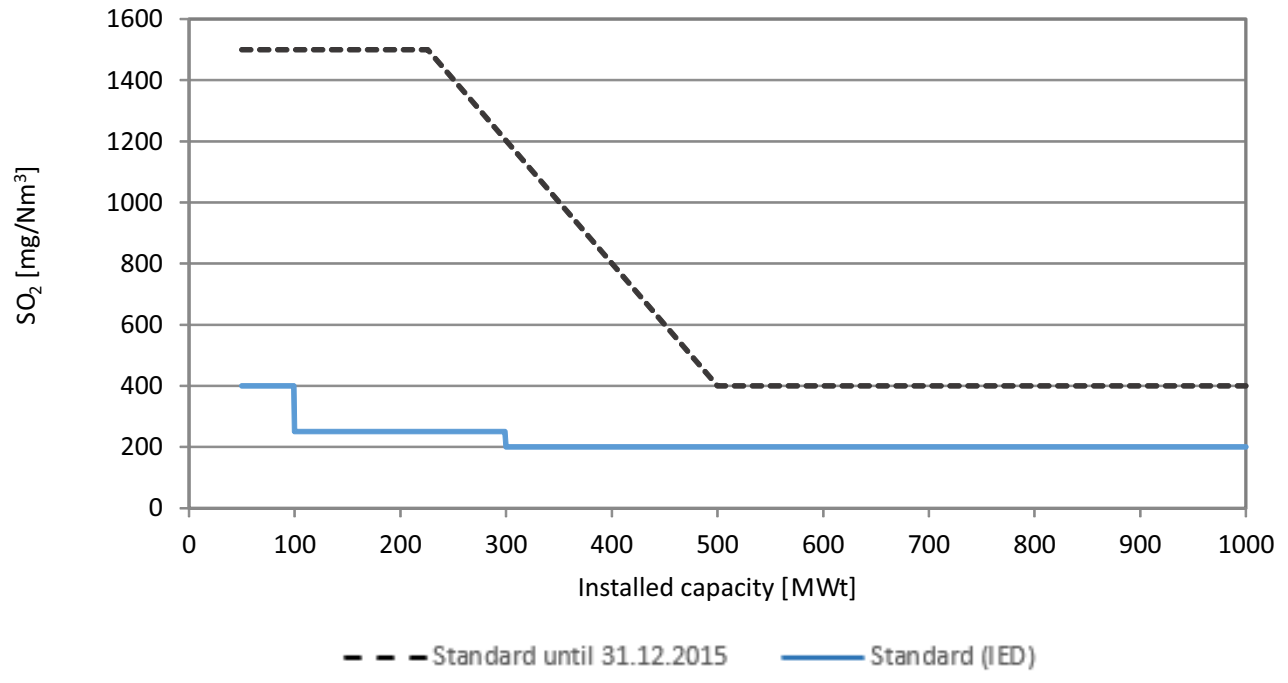

Fig. 1. $\mathrm{SO}_{2}$ emission standards for hard coal-fired plants (Directive 2010)

Rys. 1. Limity w zakresie emisji $\mathrm{SO}_{2}$ dla źródeł na węglu kamiennym

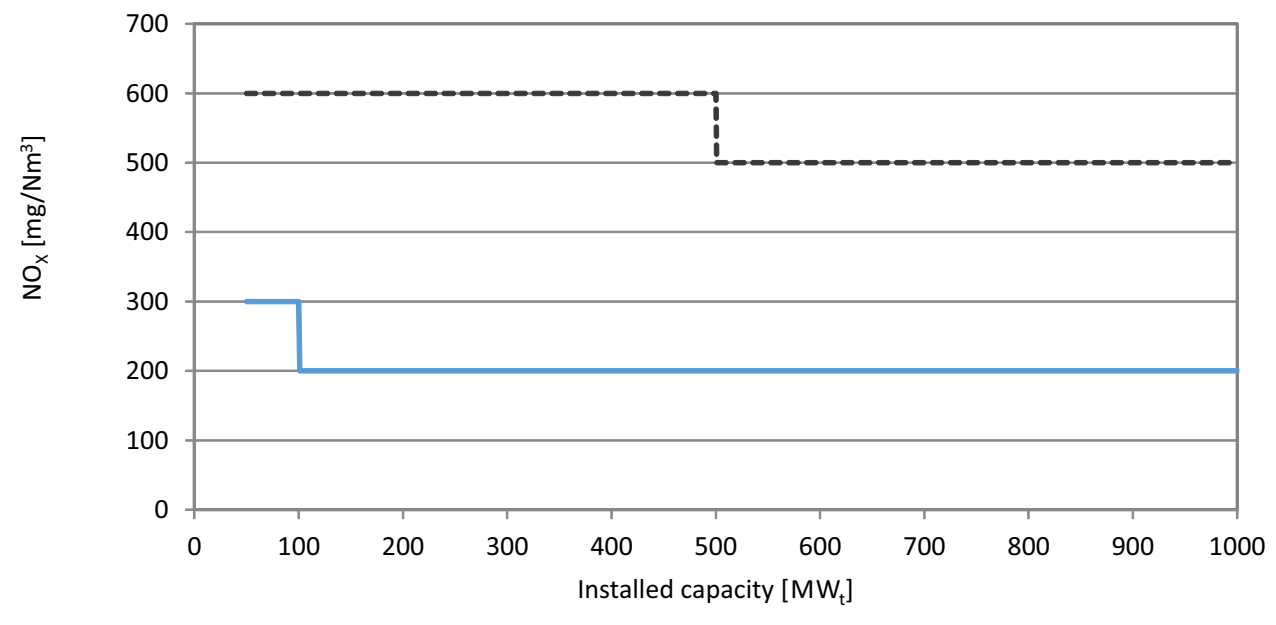

- - - Standard until 31.12.2015 $\longrightarrow$ Standard (IED)

Fig. 2. $\mathrm{NO}_{\mathrm{x}}$ emission standards for hard coal-fired plants (Directive 2010)

Rys. 2. Limity w zakresie emisji $\mathrm{NO}_{\mathrm{x}}$ dla źródeł na węglu kamiennym 


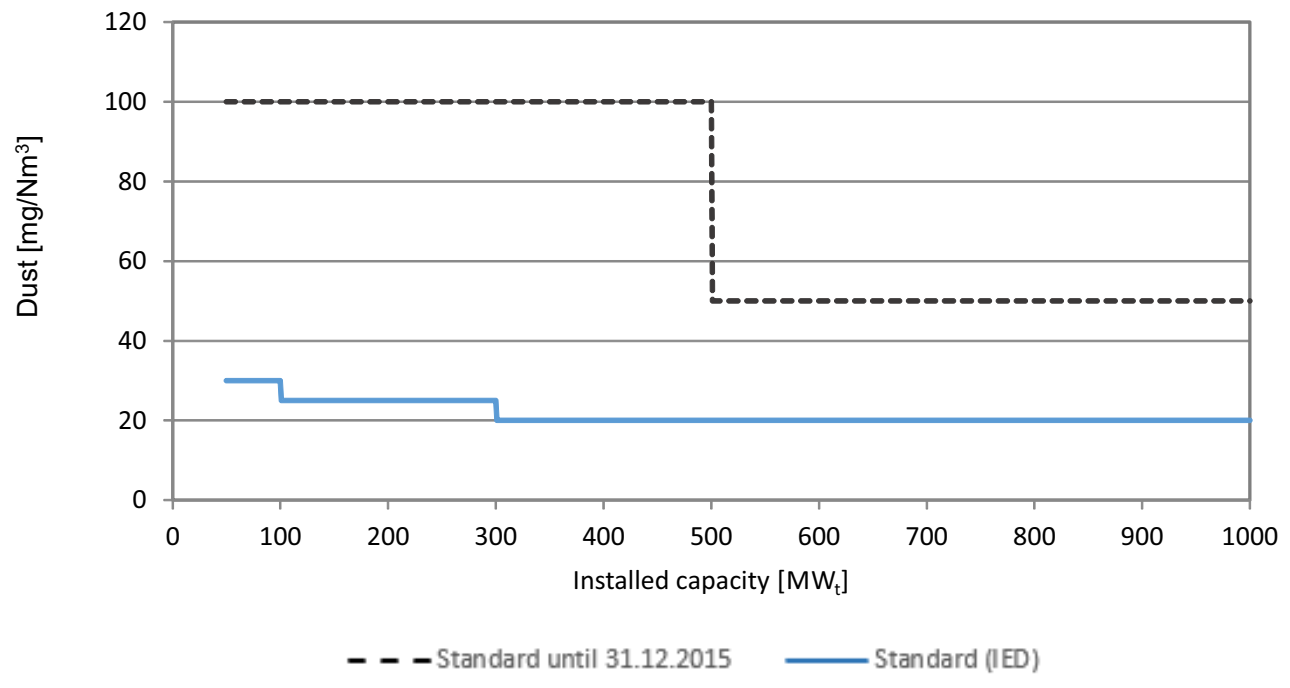

Fig. 3. Dust emission standards for hard coal-fired plants (Directive 2010)

Rys. 3. Limity w zakresie emisji pyłu dla źródeł na węglu kamiennym

2) "Opt-out" - installations which will shut down before 1 January 2023 and in 2016-2023 will not operate more than 17,500 hours were granted exemptions from the new emission requirements.

3) For peaking power units - operated no more than 1,500 h/yr, less stringent operating parameters were defined.

4) District heating - where at least $50 \%$ of the heat is generated for the public heating network by installations with a power below $200 \mathrm{MW}$ - units are exempted from new emission requirements until 31 December 2022.

All combustion installations, which at the time of implementation of the Directive had integrated permits and had not been covered by any derogation mechanisms, had to meet at least the standards specified in Annex V as of January 1, 2016. New obligations for power companies under the IED also apply to reporting issues. A new requirement has appeared, partly known from the Regulation of the Polish Minister of the Environment on emission standards, obliging the operators of installations to inform the competent authority (in Poland, Regional Environmental Protection Inspectorates) about the occurrence of disturbances in technological processes and technical operations that have led to the violation of the conditions of integrated permit. In addition, new integrated permits set out an obligation to report annually to the competent authority (including a summary of the emission monitoring results in a format that allows for a comparison with the best available techniques) so that the competent authority can assess the compliance with the conditions established in the permit. Regretfully, the suggestion of several countries to combine the reporting obligation with reporting in the E-PRTR system did not gain the support of the European Commission. 
However, bearing in mind the scope of regulations covered by the IED, one may conclude that the changes introduced by its implementation in the energy sector were unprecedented.

\subsection{BAT Conclusions - further tightening of emission requirements}

One of the main objectives pursued when commencing work on the IED was to clarify and give a greater role to the Best Available Techniques (BAT) instrument. The BREF or BAT Reference Document provides guidelines and guidance to assist the permitting authorities in setting the installations' operating parameters recorded in the integrated permit. BREFs contain provisions stating that the values presented therein are not emission limit values and should not be understood as such. Hence, the Commission's original idea that BREFs would rise to the rank of an EU-wide legal act met with great resistance. The very layout of those documents, their volume and frequently encountered unavailability in all EU languages made it impossible to implement the Commission's plan.

In order to address this problem, a new type of document, the BAT Conclusions, has been created. The conclusions constitute an extract from the BREFs and contain their most essential elements. The BAT conclusions were adopted on July 31, 2017 by a European Commission Decision (BAT Conclusions 2017) and have since become legally binding - installation operators have four years to comply with tougher requirements. The BAT conclusions affect all companies which operate installations that require integrated permits.

The achievement of those significant emission reductions (consequences of the IED and BAT conclusions) forced power companies to invest millions in flue-gas desulphurisation (deSOx) and flue-gas denitrification (deNOx) systems. According to preliminary estimates of the Ministry of the Environment, the costs of adjusting the power sector to the requirements resulting from the BAT conclusions may reach as much as PLN 10 billion.

\subsection{Transitional National Plan (TNP)}

The purpose of the Transitional National Plan, adopted in Poland on December 27, 2012 by the Council of Ministers, is to alleviate the severity of IED provisions by implementing phases for adjusting the existing sources to emission requirements. These phases (determining permitted emission ceilings in a given year) have been spread over time until June 2020. Hence, a period of 4 years and 6 months has been foreseen for technical adjustment and refurbishment of assets. The possibility of derogation was also important due to the fact that otherwise the requirements of the IED could have seriously disrupted the power supply system (decrease in available electrical and thermal inputs) if it had become necessary to exclude. In January 2016, the plants that 
had not met strict emission standards. The plan covered, by name, all generating units that had requested an additional transitional period. The installations covered by the TNP could not benefit from other transitional mechanisms and had to be put into operation not later than November 27,2003 . The final list of plants as well as the emission volumes had to be accepted by the Commission. The deadline for submitting the TNP to the Commission was January 1, 2013, and then the Commission had 12 months to examine it. When the TNP expires, it will automatically be replaced by the provisions of the IED.

The TNP proposal submitted to the European Commission included 73 industrial facilities that expressed their willingness to participate in the Plan. In the course of the year envisaged for the examination of the application, the Commission asked the Polish Government three times to remedy the gaps or to provide additional explanations. Finally, on the basis of the draft submitted plan, and the information received in the course of the case, the Commission concluded that the request was well founded, the rationale behind the need for a derogation was sufficient and that the emission ceilings for each year were duly calculated. Therefore, on February 17, 2014, the Commission issued a decision approving the TNP draft for Poland for all 73 reported combustion plants. Following that decision, on April 23, 2014 the Council of Ministers adopted a resolution (TNP 2014) approving the Transitional National Plan.

As time passed, it turned out that some entities, despite being in the 2014 TNP, managed to build appropriate installations protecting against excessive emissions of sulphur compounds, nitrogen and dust to air, and by doing so met the requirements imposed by the IED. Therefore, in May 2016, Poland adopted amendments to the existing TNP (TNP 2016), which received prior approval from the European Commission on March 3, 2016.

\subsection{Other transitional mechanisms}

Apart from the aforementioned Transitional National Plan, EU regulations also provided for another transitional mechanism for key installations from the point of view of social needs installations supplying heat to district heating networks on condition they have been put into operation non later than November 27, 2003. This derogation, also known as district heating derogation, is valid from January 1, 2016 until December 31, 2022, provided that:

$\checkmark$ a total rated thermal input does not exceed $200 \mathrm{MW}_{\mathrm{t}}$;

$\checkmark$ at least $50 \%$ of the total useful heat production is delivered to the district heating networks operating for the needs of end users.

On December 21, 2015 the Ministry of the Environment submitted a list (MŚ 2015a) of installations covered by this type of transitional mechanism which included 89 items with a total thermal power of $10,609 \mathrm{MW}_{\mathrm{t}}$ to the European Commission.

In addition to district heating derogation, EU legislation allowed for two more types of transitional mechanisms dedicated to installations intended for decommissioning and for investments to restore generation capacity. 
The first mechanism is a transitional mechanism for operating peaking power units for which the average annual operated hours, calculated as a rolling average over a period of five years, will not exceed 1,500 hours. The exemption from the need to comply with new emission standards covered by the IED has been foreseen without a time limit, as an exception for installations using solid fuel with a thermal input not greater than $500 \mathrm{MW}_{\mathrm{t}}$ when $\mathrm{NO}_{\mathrm{x}}$ emissions are taken into account, and which have been granted a permit before November 27, 2002 or for which an application has been submitted before that date, but the physical start up took place before November 27, 2003. The applicable emission ceilings for this group are:

४ $800\left[\mathrm{mg} / \mathrm{Nm}^{3}\right]$ for $\mathrm{SO}_{2}$,

$\rightarrow 450\left[\mathrm{mg} / \mathrm{Nm}^{3}\right]$ for $\mathrm{NO}_{\mathrm{x}}$.

This $\mathrm{NO}_{\mathrm{x}}$ emission ceiling of $450\left[\mathrm{mg} / \mathrm{Nm}^{3}\right]$ also applies to installations with a rated thermal input of $500 \mathrm{MW}_{\text {th }}$ or more, but only if they have been granted a permit before July 1, 1987.

The second of the aforementioned mechanisms, which primarily refers to installations planned for decommissioning after a set period of time, is the so-called natural derogation, provided for the period from January 1, 2016 until December 31, 2023 for installations meeting the following conditions:

$\downarrow$ the total number of operated hours during the derogation period shall not exceed 17,500 hours;

$\downarrow$ the operator of the installation shall report annually on operated hours of the installation;

$\downarrow$ the installation that has been submitted shall not make use of the derogation mechanism provided for in Article 4(4) of LCP Directive 2001/80/EC;

$\downarrow$ installations with a rated thermal input greater than $500 \mathrm{MW}_{\text {th }}$ and using solid fuels, which have been granted a permit for the first time after 1 July 1987 shall comply with the $\mathrm{NO}_{\mathrm{x}}$ emission ceilings laid down in Annex V (Part One) of the IED.

Despite these conditions, several derogations have been allowed for very specific types of installations which are part of small isolated power systems. The list of the Ministry of the Environment of December 21, 2015, referred to in the context of the district heating derogation, also specified the installations submitted to be covered by natural derogation (MŚ 2015b), including 36 items with a total thermal power of $15,464 \mathrm{MW}_{\mathrm{t}}$.

\subsection{Fees for economic use of the environment}

A cogeneration company is also obliged to pay fees for the economic use of the environment. The rate for the emission of harmful substances is determined by the Regulation/Announcement issued by the Minister of the Environment. The existing document, which imposes rates on power companies, CHP plants included, is the Announcement of the Minister of the Environment of October 3, 2018 on environmental fee rates for 2019. The obligation to pay these fees constitutes a significant cost for the company. Table 1 shows the individual fee rates in 2019 for discharging selected substances to the environment. 
TABLE 1. Examples of environmental fee rates in 2019

TABELA 1. Przykładowe wysokości stawek opłat za korzystanie ze środowiska w 2019 r.

\begin{tabular}{|c|l|c|c|}
\hline$\#$ & \multicolumn{1}{|c|}{ Emission type } & Fee rate & Unit \\
\hline 1 & Sulphur dioxide & 0.54 & PLN $/ \mathrm{kg}$ \\
\hline 2 & Carbon dioxide & 0.30 & PLN/Mg \\
\hline 3 & Nitrogen oxides & 0.54 & PLN $/ \mathrm{kg}$ \\
\hline 4 & Dust from fuel combustion & 0.36 & PLN $/ \mathrm{kg}$ \\
\hline 5 & Mercury & 194.49 & PLN $/ \mathrm{kg}$ \\
\hline
\end{tabular}

Source: own elaboration based on (Announcement... 2018).

\section{6. $\mathrm{CO}_{2}$ emissions trading system}

In the case of $\mathrm{CO}_{2}$ emissions to air, the situation is different compared to emissions covered by the IED. In this case, $\mathrm{CO}_{2}$ emissions are covered by the European Emissions Trading System (EU ETS) which is one of the key mechanisms for implementing the climate policy pursued by the European Commission, and the arrangements contained in the objectives of the so-called climate and energy package.

The European emissions trading system was implemented at the beginning of 2005 pursuant to Directive 2003/87/EC of the European Parliament and of the Council of October 13, 2003 and through an amendment to Council Directive 96/61/EC. The current framework for its application was defined in Directive 2009/29/EC of the European Parliament and of the Council amending Directive 2003/87/EC in order to improve and extend the Community greenhouse gas emission allowance trading scheme (the so-called EU ETS Directive). The primary objective of the implementation of the system is to persuade $\mathrm{CO}_{2}$ emitters to invest in new low-carbon technologies of their installations in order to avoid the need to purchase and incur additional and high costs of emission allowances. This structure has resulted in an economic instrument aimed at promoting emission reductions in an economically viable manner (Borys 2014). In practice, the fulfilment of this mechanism falls on the individual owners of $\mathrm{CO}_{2}$ emitting installations, who are obliged to surrender their emission allowances (EUA - European Union Allowance). A single EUA allowance is equivalent to one ton of $\mathrm{CO}_{2}$ emission. In order to ensure economic efficiency, EUAs can be traded on a stock exchange. The EUA pool can be supplemented by allowances exchanged for certificates obtained under the Clean Development Mechanism (CDM) and Joint Implementation (JI) mechanism. For activities within the abovementioned mechanisms, Certified Emission Reductions (CERs) and Emission Reduction Units (ERUs) are granted; they are exchangeable with EUAs on a one-for-one basis (Gałan 2010). The implementation of the ETS has been divided into trading periods (phases): 
the first phase for the years 2005-2007, the second phase for the years 2008-2012 and the current third phase for the years 2013-2020. The upcoming fourth phase is planned for the years 2021-2028.

In the first trading period (2005-2007), most emission allowances were granted to companies freely (grandfathering), and, at the same time, a substitution fee (EUR 40/Mg CO $\mathrm{CO}_{2}$ ) was set for exceeding the allocated emission limit. The allocation of emissions was performed in accordance with the National Allocation Plans (NAPs) established for each Member State. In the case of Poland, the plan was called National Allocation Plan for $\mathrm{CO}_{2}$ Emission Allowances - first trading period 2005-2007 (MŚ 2006). During this phase, further improvements and solutions to the emissions trading system were developed. Before the end of the first period, an unusual situation arose, namely, that the price of allowances fell to zero, which was the consequence of excessive number of allowances on the market and the inability to carry them over to the following years (Fig. 4).

In the second trading period (2008-2012), the majority of allowances were also granted freely but in a smaller quantity than before, based on the experience of the first trading period and simultaneous increase in the substitution fee (EUR 100/Mg CO 2 ). The allocation of allowances to entities and their installations was carried out according to revised national plans (MŚ 2006). The entity responsible to the Ministry of Environment for the coordination of the EU ETS during

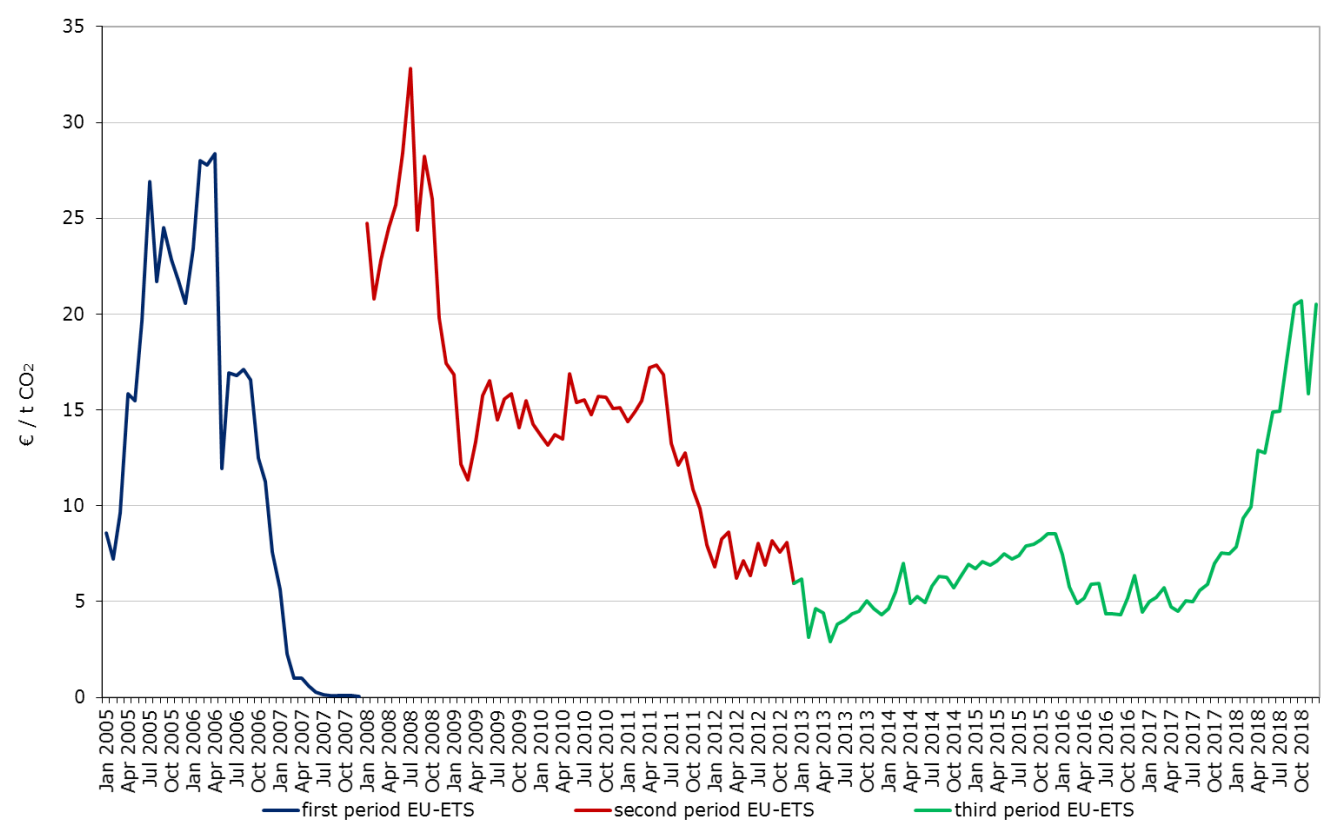

Fig. 4. Changing prices of $\mathrm{CO}_{2}$ emission allowances in the $1^{\text {st }}, 2^{\text {nd }}$ and $3^{\text {rd }}$ trading periods Source: own elaboration based on CIRE 2019 data (handel-emisjami-co2.cire.pl) Rys. 4. Zmiana cen uprawnień do emisji $\mathrm{CO}_{2} \mathrm{w}$ I, II i III okresie rozliczeniowym 
that period was KASHUE (National Administrator of the Emission Allowance Trading Scheme). Similarly to the end of the first period, the price of allowances fell significantly as a result of their excessive quantity, but not to zero anymore (Fig. 4).

A key feature introduced in the third trading period (2013-2020) of the EU ETS is the gradual shift away from free allocation of emission allowances towards an obligation to purchase them at auction. This allocation mechanism follows different pathways and criteria depending on the sector of the national economy concerned. It should also be noted that during that period, national emission limits were abandoned and changed to the single EU-wide cap.

By its Regulation No. 174/2014 of February 25, 2014, the European Commission modified the volumes of emission allowances applicable in the third trading period to be auctioned in that period (2013-2020). The reason behind was:

$\checkmark$ excessive surplus of allowances on the market (about 2 billion EUAs) created as a result of the economic recession (lower than originally thought emission levels);

$\checkmark$ a large number of allowances resulting from the conversion of certificates from the clean development mechanisms established in Kyoto.

According to market observations, the $\mathrm{CO}_{2}$ price of around EUR $5 / \mathrm{Mg} \mathrm{CO}_{2}$ did not provide sufficient economic incentive to invest in low-carbon projects. In the longer term, this situation would not allow the set emission reduction targets to be met. Against this background, the Commission decided to back-load 900 million EUAs from 2014-2016 to 2019-2020. This triggered an upward trend in the EUA price (Fig. 4). The next step taken by the European Union to change the EU ETS was Decision (EU) 2015/1814 of the European Parliament and of the Council of October 6, 2015 establishing a Market Stability Reserve (MSR) for the emissions trading scheme. Each year, $12 \%$ of the total number of allowances will be placed in the reserve over a period of 12 months beginning on the first of September of that year. In the first year of the MSR's operation, the pool will be increased by an additional $8 \%$ of the total volume.

The basic problem associated with forecasting EUA prices is that it is impossible to predict the European Commission' interference in EU ETS mechanisms. The most common attempt to avoid this issue is to use at least two (or more) scenarios containing specific EUA price pathways. On the basis of selected literature sources, the tables (Table 2) show long-term price forecasting for $\mathrm{CO}_{2}$ emission allowances.

\section{Summary and final conclusions}

Cogeneration companies are exposed to a number of various impacts, which is the effect of conducting business activity in a competitive market. Although these factors are largely outside the influence of these companies, they still put pressure on them, and the role of the company is to adapt as best as possible to the regulatory environment in force. 
TABLE 2. Long-term price forecasting for $\mathrm{CO}_{2}$ emission allowances

TABELA 2. Prognozy cen uprawnień do emisji $\mathrm{CO}_{2} \mathrm{w}$ dhugim horyzoncie czasowym

\begin{tabular}{|c|c|c|c|c|c|c|c|}
\hline Source & Scenario & Unit & 2020 & 2025 & 2030 & 2040 & 2050 \\
\hline \multirow{3}{*}{ WEO 2016} & Current Policies Scenario & EUR'14/Mg CO ${ }_{2}$ & 16.3 & - & 27.1 & 36.1 & - \\
\hline & New Policies Scenario & EUR'14/Mg CO 2 & 18.1 & - & 33.4 & 45.2 & - \\
\hline & 450 Scenario & EUR'14/Mg CO${ }_{2}$ & 18.1 & - & 90.3 & 126.5 & - \\
\hline \multirow{3}{*}{ WEO 2017} & Current Policies Scenario & EUR'16/Mg CO ${ }_{2}$ & - & 19.8 & - & 36 & - \\
\hline & New Policies Scenario & EUR'16/Mg CO ${ }_{2}$ & - & 22.5 & - & 43.2 & - \\
\hline & $\begin{array}{l}\text { Sustainable Development } \\
\text { Scenario }\end{array}$ & EUR' $16 / \mathrm{Mg} \mathrm{CO}_{2}$ & - & 56.7 & - & 126 & - \\
\hline \multirow{3}{*}{ WEO 2018} & Current Policies Scenario & $\$ 2017 / \mathrm{Mg} \mathrm{CO}_{2}$ & - & 22 & - & 38 & - \\
\hline & New Policies Scenario & $\$ 2017 / \mathrm{Mg} \mathrm{CO}_{2}$ & - & 25 & - & 43 & - \\
\hline & $\begin{array}{l}\text { Sustainable Development } \\
\text { Scenario }\end{array}$ & $\$ 2017 / \mathrm{Mg} \mathrm{CO}_{2}$ & - & 63 & - & 140 & - \\
\hline $\begin{array}{l}\text { PEP Project } \\
2050(2015)\end{array}$ & Base & EUR'10/Mg CO ${ }_{2}$ & 12.5 & - & 25 & 35 & 45 \\
\hline \multirow{2}{*}{$\begin{array}{l}\text { PEP } 2030 \\
\text { Update } \\
(2011)\end{array}$} & Base & EUR'09/Mg CO & 27 & - & 30 & 33 & - \\
\hline & High & EUR'09/Mg CO ${ }_{2}$ & 38 & - & 49 & 60 & - \\
\hline
\end{tabular}

Source: own study based on: Kaszyński 2017, IEA 2018, IEA 2017, IEA 2016, MG 2015, MG 2009, ARE 2011.

The analysis of environmental regulations shows a number of requirements imposed on cogeneration companies and affecting their long-term operation. The main task of a company in terms of meeting these requirements is to obtain an integrated permit, which requires compliance with the relevant regulations. The key issues in this respect are: proper management of water and wastewater, and compliance with the BAT conclusions on the emissions of harmful substances into air; these mainly include the emissions of: $\mathrm{SO}_{2}, \mathrm{NO}_{\mathrm{x}}$, dust, and $\mathrm{Hg}, \mathrm{HCl}, \mathrm{HF}$. The implementation of emission targets is carried out in a variety of ways, though. In the case of $\mathrm{CO}_{2}$, a decisive role is played by the emissions trading system causing the company to incur increased operating costs which are the effect of $\mathrm{CO}_{2}$ emission allowance prices. The article comprehensively discusses the conditions that substantially affect the long-term growth of a cogeneration company and are crucial when making assumptions for addressing strategic development issues in the domestic fuel and power sector.

\section{References}

ARE 2011. Update forecast for fuel and energy demand by 2030, Warszawa.

BORYs, G. 2014. The EU greenhouse gases emission trading scheme in the third trading period - assessment attempt (Unijny system handlu emisjami gazów cieplarnianych $w$ trzecim okresie rozliczeniowym - próba oceny). Financial Sciences 1(18), pp. 19-26 (in Polish). 
CIRE 2019. Prices of $\mathrm{CO}_{2}$ emission allowances (Ceny uprawnień do emisji $\mathrm{CO}_{2}$ ) (2012-2019) [Online] https://handel-emisjami-co2.cire.pl/st,34,514,me,0,0,0,0,0,ceny-uprawnien-do-emisji-co2.html [Accessed: 2019-08-28] (in Polish).

BAT Conclusions 2017. Commission Implementing Decision (EU) 2017/1442 of 31 July 2017 establishing best available techniques (BAT) conclusions, under Directive 2010/75/EU of the European Parliament and of the Council, for large combustion plants (notified under document C(2017) 5225) [Online] https://eur-lex.europa.eu/legal-content/EN/TXT/?qid=1503383091262\&uri=CELEX:32017D1442] [Accessed: 2019-08-28].

Directive 2010. Directive 2010/75/EU of the European Parliament and of the Council of 24 November 2010 on industrial emissions (integrated pollution prevention and control) [Online] https://eur-lex.europa.eu/ legal-content/EN/TXT/?uri=celex\%3A32010L0075].

GAŁAN, A. 2010. Elastic mechanisms: Joint Implementation - JI, Clean Development Mechanism - CDM. XII Doroczne Spotkanie Klubów Czystego Biznesu, Zakopane, November 5, 2010 (in Polish).

IEA 2016. World Energy Outlook 2016, International Energy Agency, Paris.

IEA 2017. World Energy Outlook 2017, International Energy Agency, Paris.

IEA 2018. World Energy Outlook 2018, International Energy Agency, Paris.

KAMIŃSKI, J. and Stós, K. 2014. Environment-related determinants of the functioning of an energy company in Poland: case study of a combined heat and power plant. Polityka Energetyczna - Energy Policy Journal, Vol. 17, No. 2, pp. 113-122.

KASZYŃSKI, P. 2017. An assessment of the prospects of solid fossil fuels demand in the power industry in terms of selected environmental regulations. PhD dissertation. Kraków: MEERI PAS Publishing House.

KUCOWSKI et al. 1997 - KUCOWSKI, J., LAUDYN, D. and PRZEKWAS, M. 1997. Energy and environmental Protection. Warszawa: Scientific and Technical Publishing House.

MG 2009. Polish energy policy until 2030, Ministry of Economy, Warszawa.

MG 2015. Polish energy policy until 2050 - project, Ministry of Economy, Warszawa.

MŚ 2006. National Plan for the Distribution of $\mathrm{CO}_{2}$ Emission Allowances (2008-2012), Ministry of Environment, Warszawa.

MŚ 2015a. List of combustion plants (sources of fuel combustion) reported for a heating derogation ( Wykaz obiektów energetycznego spalania (źródet spalania paliw) zgłoszonych do derogacji ciepłowniczej, o której mowa wart. 35 ust. 1 dyrektywy 2010/75/UE) (in Polish).

MŚ 2015b. List of combustion plants (sources of fuel combustion) reported for a derogation (Wykaz obiektów energetycznego spalania (źródet spalania paliw) zgłoszonych do derogacji naturalnej), o której mowa wart. 33 ust. 1 dyrektywy 2010/75/UE (in Polish).

Announcement... 2018. Announcement of the Minister of the Environment of October 3, 2018 on fees for using the environment for 2019 (Obwieszczenie Ministra Środowiska z dnia 3 października 2018 r. w sprawie wysokości stawek opłat za korzystanie ze środowiska na rok 2019) (in Polish).

Wastewater Treatment Manual 2010. Guidance on waste water management in the context of the implementation of the National Program of Municipal Wastewater Treatment, 2010. National Economy Board Water, Warszawa.

StAlA-SzlugAJ, K. 2012. Solid waste from hard coal combustion in the municipal and housing sector. Rocznik Ochrona Środowiska - Annual Set The Environment Protection, No. 14, pp. 909-918.

ZMYSŁOWSKA, A. and NOWAKOWSKI, T. 2004. Integrated permits (IPPC). The procedure for issuing integrated permits. Warszawa: Ministry of Environment. 


\title{
Analiza wybranych regulacji środowiskowych wpływających na długoterminowe funkcjonowanie przedsiębiorstw kogeneracyjnych
}

\begin{abstract}
Streszczenie
W niniejszym artykule podjęto próbę zidentyfikowania uwarunkowań środowiskowych rozwoju przedsiębiorstwa kogeneracyjnego w Polsce. Artykuł systematyzuje wiedzę o regulacjach środowiskowych w odniesieniu do przedsiębiorstwa kogeneracyjnego. W ramach zidentyfikowanych uwarunkowań środowiskowych autorzy scharakteryzowali zagadnienia związane z krajową legislacją regulująca działalność przedsiębiorstw kogeneracyjnych, jak również wymagania wynikające $\mathrm{z}$ regulacji unijnych i krajowych w tym zakresie. Regulacje te, w sposób bezpośredni i pośredni kształtują długoterminową przyszłość przedsiębiorstw kogeneracyjnych i całego sektora energetycznego w Polsce. Bezsprzecznie, w aktualnym stanie obowiązujących regulacji środowiskowych kluczową zmianą dla przedsiębiorstwa energetycznego, jakim jest przedsiębiorstwo kogeneracyjne, jest spełnienie wymagań dotyczących emisji substancji szkodliwych. Zmiana ta wprowadzona została w 2016 roku na skutek zaostrzonych limitów emisyjnych wraz z przyjęciem Dyrektywy w sprawie emisji przemysłowych. Wdrożenie w 2017 roku Konkluzji BAT dodatkowo zaostrzyło wymagane limity. Kluczowy dla przedsiębiorstw kogeneracyjnych będzie rok 2021, w którym zaczną obowiązywać nałożone limity emisji. W artykule zostały przedstawione kompleksowo uwarunkowania, mające decydujący wpływ na długoterminowy rozwój przedsiębiorstwa kogeneracyjnego, co jest istotne przy formułowaniu założeń dla rozwiązywania problemów z obszaru strategicznego rozwoju krajowego sektora paliwowo-energetycznego.
\end{abstract}

SŁOWA KLUCZOWE: regulacje środowiskowe, kogeneracja, konkluzje BAT 
